\title{
ALEXA PÉTER
}

\section{The Khon Clan and the Sakyapas}

The Khon ('Khon) ${ }^{1}$ is one of the great clans of Tibet which created a stable princedom in the area of Sakya (Sa skya) in southern Central Tibet, after the imperial period of Tibet.

Khon Konchog Gyalpo ('Khon Dkon mchog Rgyal po, 1034-1102), the main disciple of Drogmi Lotsawa Yeshe (Brog mi Lo tsa wa Ye shes, 992-1072), founded a monastery at Sakya in 1073. It was this monastery that gave its name to the whole monastic order of Drogmi. Konchog was a member of the Khon clan, the family that went on to produce the successive abbots or chief lamas of Sakya who have continued as the heads of this order ever since until today. The succession of abbots within the family was established on the father to son or uncle to nephew pattern. In the instance of an abbot could remain celibate (this was not obligatory), it was his brother or a close relative who continued the family line and controlled the monastery's worldly affairs. When the abbot died, he was succeeded by either one of his sons or nephews.

The Sakyas reached the summit of political power in the $13^{\text {th }}$ century when Sakya Pandita Kunga Gyaltsen (Sa skya Paṇdita Kun dga' Rgyal mtshan, 1182-1251) and later the next abbot, Chogyal Phagpa (Chos rgyal 'Phags pa, 1235-1280) won the confidence and favour of Mongolian khans. Sakya Pandita and Phagpa were appointed as regents of Tibet whereby Tibet became subject to a single political authority for the first time after the collapse of the monarchy in the $9^{\text {th }}$ century.

The aim of this paper is to show the development of the Khon clan, how a minor aristocratic family transformed into a significant power in Tibet in both historical and religious aspects, through the efforts of some prominent members of Khon family.

${ }^{1}$ In the text the Lhasa pronuncation of the Tibetan words and phrases is used, in the brackets the written forms are indicated. 


\section{The Khon family in the period of the first diffusion of Buddhism in Tibet}

The exact political position of the Khon clan during the imperial period of Tibet is uncertain. The lists of clan dominions of these times do not mention the Khons at all, although certainly not all clans are represented, including the important Lang (Rlang) and Gar (Gar) families. The Khon family probably were minor aristocrats in the area of Lhato (Lha stod) in Tsang (Gtsang) where they had a well-selected but politically insignificant estate. ${ }^{2}$

Because of the instabilities of Tibetan power after the dynasty's collapse in the mid-ninth century, the aristocratic houses in potential positions of authority tried to augment their political reputation by presenting themselves as being divine, according to either Tibetan or Buddhist standards of divinity. The Khon family skilfully constructed a myth that they were both Tibetan and Buddhist. The early version of this myth is apparent in the Red Annals of 1363 and the legend of the Khon family's origin grew over time, particularly after the $12^{\text {th }}$ century. ${ }^{3}$

This legend begins with three "celestial gods" (Tib. gnam lha): "Long life", Tshering (Tshe ring), "Long turquoise", Yuring (G.yu ring) and "Grizzled hair", Use (Dbu se) who dwelt in the realm of the gods of clear light. One day they descended from their celestial abode to the realm of men at Crystal Mountain (Tib. Shel dkar) which is located in the mountain range known as Namla (Gnam la) in the far north of Tibet, in the border region between Tibet and Mongolia. These gods who had come down with their entourages enjoyed great wealth and splendour. They displayed various signs of the wealth gods, such as the wish-fulfilling cow and dwelt in the sky in a golden celestial mansion, a place decorated with turquoise, fine precious stones and jewels. ${ }^{4}$

Yuring, one of these gods, was attracted to one of the daughters of the Tibetan $\mathrm{Mu}(\mathrm{Dmu})$ clan leader and "received her in his fortress." They had seven sons and six of them decided to return to the divine realm with their father via the sacred "mu-rope" (Tib. dmu thag). ${ }^{6}$ The seventh son lived in the world of men which was located in the "intermediate realm" (Tib. bar snang) between the sky

2 Hardy 1999: 254.

${ }^{3}$ Davidson 2008: 270-271.

${ }^{4}$ Chogye 2003: 17.

${ }^{5}$ An allusive vocabulary of Tibetan honorifics. Davidson 2008: 270.

${ }^{6}$ The $m u$-rope signifies the connection between earth and heavens which is present in numerous Tibetan folk and religious practices. In the earliest version of the legends of Tibet's mythological kings, the first king and his six descendants returned every night to their divine home in the sky with the $m u$-rope that was attached to the crown of his head. Upon death, they returned permanently to the heavens having no need for earthly tombs. Sumegi 2008: 22. 
and the earth. His son, Yapangkye (G.ya' spang skyes) was born at the border between a mossy "meadow" (Tib. spang) and slate "hillside" (Tib. g.ya'). He took up residence on a high mountain northwest of the Shang (Zhang) area of Tibet, a mountain that came to be known as Yapang's mountain or Yapangri (G.ya' spangs ri). ${ }^{7}$

In those ancient times there were some demonic beings dwelling in the foothill of this mountain and in caverns below their base. Yapangkye became attracted to the beautiful wife of a demon so he killed the demon and took his widow as his bride. A son was born to them who - in honour of his being conceived through the "struggle between a god and a demon" (Tib. lha dang srin po 'khon pa) - was given the name Yapang Khonbarkye (G.ya' spangs 'Khon bar skyes). Thus the Khon family name came from the "struggle" (Tib. 'khon) between a celestial god and a demon in Central Tibet. ${ }^{8}$

When Khonbarkye grew up, he married a woman from Tsang and she gave birth to a son, Khonpa Jegungtag ('Khon pa Je gung tag) and thus the Khon lineage began. Khonpa Jegungtag established his fiefdom at Nyentse tangsho (Gnyan rtse Thang shod) in the western part of Tsang. As King Thrisong Detsen (Khri srong Lde btsan, 742-797) esteemed him so greatly, he was entrusted with the high office of "minister of the interior" (Tib. nang rje kha) and became known as Khon Palpoche ('Khon Dpal po che), the Great Glorious Mr. Khon. ${ }^{9}$ During this period, the Khon family specialized in the Nyingma (Rnying ma) tradition of Tibetan Buddhism.

Khon Palpoche's elder son, Khon Lui Wangpo ('Khon Klu'i Dbang po) was a disciple of Padmasambhava (Tib. Pad ma 'byung gnas, 750-800?), a legendary Indian Buddhist mystic. He became one of the "seven good men" (Tib. sad mi mi bdun) who were in the first group of Tibetans ordained by Shantarakshita (Skt. Sāntarakṣita, Tib. Zhi ba tsho, 705-788) at the newly constructed monastery of Samye (Bsamyas). ${ }^{10}$ His younger son, Khon Dorje Rinchen ('Khon Rdo rje Rin chen) also received all the teachings from Padmasambhava but to continue the Khon lineage he married a wife and had seven sons.

Neither the name of Jegungtag, nor the names of Palpoche's sons appear in the early surviving documents. What is evident, is that the Khon family was largely kept at the periphery of the dynasty, irrespective of their court presence. The earliest Khon records did not mention the imperial appointment of Jegungtag; they begin with Lui Wangpo, although the information about him is

\footnotetext{
7 A district of Tsang, north of Tashilhunpo (Bkra shis lhun po).

8 Davidson 2008: 268.

9 Smith 2001: 100.

${ }^{10}$ Kunga 2003: XXVII-XXVIII.
} 
sparse. Sakya and Nyingma writers include him likewise among the disciples of Padmasambhava, that is apparently a later view about the imperial period. ${ }^{11}$

\section{The Khon family in the age of feudal disintegration}

Through the $10^{\text {th }}$ and $11^{\text {th }}$ centuries the aristocratic clans and regional lords became the centres for both political power and religious authority, sometimes vested in the same person. The Tibetan aristocracy possessed a variety of estates distributed throughout Tibet and they made marital alliances based on social status and benefit. ${ }^{12}$

The Khon clan became visible among the Tibetan aristocracy when Lui Wangpo's younger brother, Khon Dorje Rinchen married a girl of the Dro ('Bro) clan. The Dro family, along with the Khyungpo (Khyung po), were the powerful clans in Tsang during and following the imperial period. Dorje Rinchen's seven sons planned to challenge the dominion of their Dro relatives thus the Dro chieftain with a group of his armed men strove to deal with this problem. In the end, the youngest son remained in Tsang and contended with the Dro clan alone, while the six elder sons left the area and relocated widely throughout western and southern Tibet - in Mangyul Gungtang (Mang yul Gung thang), Nyaloro (Gnya' Lo ro) and Nyangshab (Nyang shab) - establishing the Khon clan in each of these areas. ${ }^{13}$ Their descendants became known as the "eight groups of the Khon" (Tib. 'Khon tsho brgyad) in that area.

Dorje Rinchen's sixth son, Sherab Yontan (Shes rab Yon tan) lived in Yarlung (Yar klung). His great-great grandchild, Khon Shakya Lodro ('Khon Shākya Blo gros) had two sons, the elder son was Khon Sherab Tshultrim ('Khon Shes rab Tshul khrims) and the younger was Khon Konchog Gyalpo. The two brothers were heirs to a long tradition of ritual systems dating from the period of the first diffusion of Buddhism in Tibet. They decided that the efficacy of these teachings declined because they were taught openly in violation of the tantric requirement of secrecy. They deemed that their inherited teachings were irreparably corrupted and consequently took all texts and ritual implements and sealed them into a stupa. ${ }^{14}$

11 Davidson 2008: 270.

12 Davidson 2008: 80.

13 Davidson 2008: 271.

${ }^{14}$ According to the Sakya legend, the protective deities told them that the Vajrakumara system (Skt. Vajrakumāra, Tib. Rdo rje gzhon nu) of Vajrakilaya (Skt. Vajrakīlaya, Tib. Rdo rje Phur ba) and certain Yangdag Heruka (Yang dag He ru ka) cycles were to be exempted from this kind of house cleaning. These cycles thus remained part of the Khon rites and continued to be part of the Sakya teachings. 
Sherab Tshultrim, a celibate layman, was a disciple of an Eastern vinaya monk, Zhuton Tsondru (Zhu ston Brtson 'grus). Konchog became interested in this newly emerging direction of Buddhist practice and literature represented by Zhuton Tsondru. Konchog met many eminent translators and scholars who had travelled to and from India. One of them was Drogmi Lotsawa Yeshe who had returned from extensive studies in India. Konchog took him as his teacher despite Drogmi's demand of a high fee for his teachings, which resulted in Konchog selling some of the land he owned in Yarlung and presenting seventeen horses to Drogmi. After he finished studying with Drogmi, Konchog began to teach and constructed a centre in Drawolung (Bra bo lung) close to Yarlung. Soon it became too small for the growing group of his disciples so he sought a new location. ${ }^{15}$ Passing through a valley he was impressed by its auspicious features which included a mountain that looked like an elephant's trunk, a pale grey soil and good water sources. He obtained permission from the local lords to build a temple. In 1073 he finally completed Gorum Zimchi Karpo (Sgo rum Gzims spyi Dkar po). This event is considered the founding of the Sakya Monastery, from which the small temple eventually developed. The monastery and the tradition that Konchog established there came to be named after the landscape in that area hence the name Sakya "gray earth". Later the name of Sakya came to be more commonly associated with the family than their original name of Khon. ${ }^{16}$ The Sakya monastery was regarded as the seat of great "vajra holders" (Tib. rdo rje 'chang) or "throne holders", tridzins (Tib. khri 'dzin). The thirty-nine-year-old Konchog accordingly is counted as the first throne holder of Sakya, a post he occupied from 1073 to 1102 , the year he died. ${ }^{17}$

\section{The Khon family in the period of the second diffusion of Buddhism in Tibet}

Konchog, as one of the new religious leaders took the place left by the old feudal nobility and also became prominent in worldly affairs. The Buddhist monasteries became centres of learning and religious life and also of economic power, thus creating a new monastic aristocracy. ${ }^{18}$

15 Davidson 2008: 273.

16 The Treasury of Lives 2007.

${ }_{17}$ About the rise of the Sakya sect there are three basic and authoritative works: (1) Sa skya' $i$ gdung rabs chen po rin chen bang mdzod by 'Jam mgon A myes zhabs Ngag dbang Kun dga' bsod nams (1597-1662), (2) The supplement (Tib. kha skong) to the above, Rin chen 'dzad med by Sachen, (3) The supplement (Tib. kha skong) to the above, Sa skya'i gdung rabs mtshar rin chen kun 'phel by Sa skya pa Drag shul phrin las (1871-1935). Smith 2001: 101.

${ }^{18}$ Hoffmann 1975: 53. 
When Konchog passed away, his eleven-year-old son, Sachen Kunga Nyingpo (Sa chen Kun dga' Snying po, 1092-1158) was too young to replace his father and therefore Sachen's teacher, Bari Lotsawa (Ba ri Lo tsa wa, 1103-1111), the great translator became the second Sakya throne holder. ${ }^{19}$ Sachen was twenty years old when he replaced his teacher. ${ }^{20}$

Following the founding of the Sakya order in 1073, the Sakya tradition rose to prominence in Tibet from the time of Sachen through the efforts of the next four great Sakya masters: Sonam Tsemo (Bsod nams Rtse mo, 1142-1172), Dragpa Gyaltsen (Grags pa Rgyal mtshan, 1147-1216), Sakya Pandita and Chogyal Phagpa. These five masters are regarded as the real founders of the Sakya tradition. They were known as the "five patriarchs" or "three whites and two reds", which means the three laypersons and two monks. ${ }^{21}$

Sachen's most outstanding teacher was his paternal relative, Khon Kyichub Dralhawa ('Khon Skyi chub Gra lha ba) who appointed him to take over his monastery and the numerous disciples. Sachen accepted his uncle's offer but he remained a layman so he could have children and carry on his family lineage. Tibetan yogin Zhangton Chobar (Zhang ston Chos 'bar, 1053-1135) transmitted to Sachen the "path and its result", lamdre (Tib. lam 'bras) teaching, the core of the Sakya tradition. Lamdre is a system of knowledge of practicing the entire range of sutric and tantric teachings of the Buddha. These teachings were brought to Tibet by the Indian scholar Gayadhara (994-1043) and were translated by Drogmi Lotsawa. ${ }^{22}$ In 1141 Sachen's first disciple was Jangchub Sempa Aseng (Byang chub Sems pa A seng), an important monk from Kham (Khams), and was followed by Sachen's own sons Sonam Tsemo and Dragpa Gyaltsen.

The two sons, who were his closest disciples, became the forth and fifth Sakya throne holders and patriarchs. Sonam became an excellent scholar renowned in Tibet and India, whilst Dragpa remained at Sakya and chose the path of a reclusive meditator becoming a great accomplished master in Tibet.

Sachen's youngest son, Palchen Opo (Dpal chen 'Od po) never held the throne but was the father of Sakya Pandita Kunga Gyaltsen, the important scholar and the sixth Sakya patriarch. Sakya Pandita was the principal disciple of his uncle, the great Dragpa. ${ }^{23}$ Sakya Pandita taught widely and became renowned across Tibet for his scholarship and skill in teaching. His writings are counted among the most widely influential in Tibetan literature and prompted commentaries by

\footnotetext{
19 Bari Lotsawa is the only master who was not part of the Khon family in the lineage of throne holders of the Sakya school.

${ }^{20}$ Chogye 2003: 20.

${ }^{21}$ Sakya Heritage Society n.d.

22 The Treasury of Lives 2007.

${ }^{23}$ Chogye 2003: 23.
} 
countless subsequent authors. His works on Buddhism were so significant that they were translated into Indian languages.

As a distinguished scholar in all fields of science and study, he drew the attention not only of the people of Tibet but of all neighbouring countries as well. In 1244 Sakya Pandita received an invitation to present a report to the court of Prince Goden, the son of the supreme Mongolian leader, Ogodei (1186-1241). Goden was in charge of the regions of the Mongolian Empire that bordered on Tibet. Following the practice of Genghis Khan (1162-1227) and his successors, Goden also enumerated the foremost sects which could confer about the circumstances in Tibet, and he selected the Sakyapa sect. ${ }^{24}$ Tibetan historians present the events with Sakya Pandita going to Mongolia to serve as religious preceptor. However, it is more likely that he was summoned to serve as proxy for Tibetan acceptance of Mongolian rule.

The sixty-three-year-old Sakya Pandita and his two nephews, the heirs to the Khon family, made a journey to meet Goden in the Karakorum region. The sons of his brothers, Chogyal Phagpa and Chagna Dorje (Phyag na Rdo rje, 1239-1267) went along as disciples and attendants to their teacher and uncle. The two young men both later played important parts in the history of Tibet, Mongolia and China. ${ }^{25}$

According to Tibetan histories, in 1249 Sakya Pandita became the Mongol "representative" (Mong.: darugachi) and thus wielded power throughout Tibet. Sakya Pandita and Goden reached an agreement whereby Tibet would acknowledge Mongolian sovereignty and agree to a fixed tribute. Mongolian secretaries and treasurers entered the country to supervise the collection and payment of tribute. Sakya Pandita remained in the Mongol camp for years and sent a letter to other leaders in Tibet urging them to submit to the Mongol rule and pay tribute. He pointed out that resistance would be not only impossible but disastrous, too. Tibetan nobility revolted and did not want to accept the ruling of the Sakya abbot but the insurrection was suppressed by Mongol troops.

Sakya Pandita's relationship with Goden is often cited as a model for the later development of the so-called "priest-patron" (Tib. mchod yon) relationship between Tibet and its - in military aspect - more powerful neighbour, Mongolia. Sakya Pandita's ventures in Mongolian power also helped to lay the ground for the long standing tradition of linking Buddhist authority and political rule in Tibet. ${ }^{26}$

Beside his political activities, Sakya Pandita also gave Goden religious instruction and cured him of a serious illness, probably leprosy. It seems that

\footnotetext{
${ }^{24}$ Sagaster 2007: 383.

25 Wylie 1977: 104-115.

${ }^{26}$ The Treasury of Lives 2007.
} 
Sakya Pandita made a deep impression with his sense of diplomacy and great wisdom onto the tolerant Mongolians.

The young boys, Phagpa and Chagna grew up at the court and were educated in Mongolian and Tibetan languages by their uncle. When Goden and Sakya Pandita died almost at the same time, Phagpa and Chagna had to leave the court of Goden and the prince's descendants were no longer connected with Tibetans.$^{27}$ Chagna spent his whole life in Mongol surroundings with his wife, Goden's daughter. His political role was never clarified as his life was cut short by his early death. ${ }^{28}$

In 1253 the new great khan, Kubilai (1215-1294), invited Sakya Pandita to his newly built city of Kaiping (latter known as Shangdu) to teach his son, Jingim (1243-1286) Buddhist intellectuality and spirituality. Sakya Pandita passed away in 1251 and so Phagpa took his place. Phagpa, the seventh throneholder, was well known and highly esteemed among Tibetan and Mongolian Buddhists as the nephew of Sakya Pandita and a member of the powerful Khon family. Phagpa settled at Kubilai's court and he gained a significant degree of influence and authority. He had a unique position in regard to both Mongols and Tibetans and therefore was particularly suited to form an alliance, the so-called dual rule with Kubilai. ${ }^{29}$ They shared ecclesiastical and secular powers: the lama presided over religious affairs and the khan over secular affairs in their dual rule. ${ }^{30}$ Phagpa had both religious and administrative duties. He was authorised to propagate the Buddhist doctrine, to give explanations of the religious scriptures, to found monasteries and to pray for the longevity of the emperor and the well-being of the state. His most important political and administrative duty was the administration of all matters relating to the Buddhist clergy in the entire empire and the responsibility for all Tibet. ${ }^{31}$ The Khan offered "thirteen myri-

${ }^{27}$ In 1251, Goden's cousin, Mongke (1209-1259) became the great khan of the Mongol Empire. He gave his younger brother, Kubilai control over the Chinese territories in the eastern part of the empire. Monke entrusted him with the responsibility of unifying China under the Mongol Empire. However, Mongke was killed while leading an expedition into Western China in 1259 and Kublai was elected as Mongke's successor in 1260. In 1278, he destroyed the Sung dynasty and established the Yuan dynasty. Kubilai became the leader of an empire that stretched across two continents: he became the overlord of all the Mongol dominions (the Golden Horde in southern Russia, the Il-Khanate of Persia and regions inhabited by the traditionally nomadic Mongol princes), as well as the ruler of his own territory of China.

${ }_{28}$ Petech 1990: 20.

29 Phagpa and Kubilai agreed on a new alliance the so-called "two laws" in Mongolian qoyar yosun, while Tibetan use three phrases: "two modes", gnyis lugs; "two laws", khrims gnyis and "two-protective", gtsug gnyis lag.

${ }^{30}$ Migmar 2008: 245-247.

31 Grousset 1970: 304. 
archies" (Tib. khri 'khor bcu gsum) to Phagpa, which approximately included U (Dbus), Tsang and Ngari (Mnga' ris). ${ }^{32}$

In 1268 Kubilai requested Phagpa to devise a new script ${ }^{33}$ to be employed for Mongolian, Tibetan and Chinese. He created the so-called Phagpa alphabet ${ }^{34}$ on the basis of the Tibetan writing system. Although one year later it was declared as the national script and its use was required in official documents, it never gained general acceptance. ${ }^{35}$

Kubilai nominated Phagpa national and imperial preceptor ${ }^{36}$ and issued a document, the "Pearl Edict" (Tib. 'Ja sa mu tig) which exempted the monks from taxation as well as military and labour service. ${ }^{37}$ It was a reconfirmation of the privileges granted by Chinggis Khan long before. ${ }^{38}$ Phagpa's authority over Tibet was consistently challenged by the monks of the Drigung monastery ('Bri gung dong) of the rival Drigung ('Bri gung) sect. When Sakya Pandita left this monastery the new abbot of Sakya, Shakya Zangpo (Shakya Bzang po) was given the new office of "great authority", ponchen (Tib. dpon chen) and given a centralized system of administration with civil, judicial and military authority over all of Tibet. There were the thirteen "local lay and monastic rulers", tripons (Tib. khri dpon) under this official who directly ruled in their own myriarchies. The office of ponchen functioned for all practical purposes in the same way as the Tibetan government, i.e. at the pleasure of the Mongol khans and later Yuan emperors, and it was subordinate to the national preceptor. The ponchen was invariably a Tibetan person nominated by the ruling Sakya lama and approved by the reigning emperor. ${ }^{39}$

32 Dawa 2001: 55.

33 The Mongolian official correspondence of Kubilai's empire was conducted in the old Mongolian alphabet adopted by Chinggis in about 1204. This was a late form of the old Uygur alphabet which by that time contained no more than 14 letters, many of them polyphonic and easyly to be mixed up with one another. On the other hand Kubilai's Chinese official business was carried on in Chinese, a language which his Mongol kinsmen and principal officers might perhaps speak, but could certainly not read, nor write. So he wanted urgently a good "one letter, one sound; one sound, one letter" alphabet, easy to read and suitable for writing both official languages of his empire. Clauson 1959: 301.

${ }^{34}$ It consisted of forty-one letters, many of which were square in shape. Accordingly it is also referred to as "square-script".

35 Petech 1990: 22.

${ }^{36}$ Historically, “imperial preceptor" (Ch.: 国师 guo shi) appeared before "national preceptor" (Ch.: 帝师 di shi); functionally di shi supplanted guo shi as the highest clerical honour and marked a development in the relationship between throne and sangha. Guo shi originally functioned as a religious tutor to the emperor and his family. Dunnel 1992: 86-87.

37 Petech 1990: 16-18.

38 Petech 1990: 16.

39 Dawa 2001: 55. 
Returning to Sakya in 1274 Phagpa spent his last few years in semi-retirement. There he convened a council of lamas at Chumig Ringmo (Chus mig Ring mo), known as the "Chumig Chokor" (Tib. Chus mig Chos 'khor), for religious discussions and to persuade the leaders of various traditions to accept MongolSakya rule. It was a fruitless effort as the Drigung sect continued to resist. The refusal of the Drigung monastery to accept the arrangement forced Kubilai to send troops to enforce Sakya control and Mongol control of Tibet was restored within a year.

Soon after a postal system was devised, taxes were imposed and a Tibetan militia was formed, all under Mongol direction. The system of governance devised for Tibet consisted of an imperial preceptor (Phagpa being officially the first), who was in charge of Buddhists throughout the empire as well as in Tibet and a second Mongol-appointed official, the ponchen, who lived in Tibet and administered the region more directly. This system was in place for the next eighty years. Phagpa and Kubilai also deepened their relationship through marriage alliances; Phagpa's younger brother, nephew and grandnephew all married Mongol princesses. ${ }^{40}$

Phagpa was able to use the power and other resources of his position to further his uncle's scholarly and cultural projects. With the aid of the ponchen, Phagpa built Lhakang Chenmo monastery (Lha khang Chen mo) at Sakya, which was a centre of scholarly activity of Phagpa and his successors. Sakya Pandita established the study of the five sciences ${ }^{41}$ across Tibet and Phagpa maintained the momentum through his writing and polemics. He sponsored the translation of poetry, literature and metrics. It was also largely thanks to the Sakya influence that Sanskrit poetry became the basis of high literary culture during this time. ${ }^{42}$

In 1280, the year after Kubilai conquered the remnants of the Song dynasty, Phagpa died at Sakya, allegedly poisoned by an unpopular ponchen. With Mongolian support, the Khon family ruled Tibet until the middle of the $14^{\text {th }}$ century. ${ }^{43}$ After the death of Kubilai in 1295, the power of the Mongols began to decline in China. In 1305 Zangpo Pal (Bzang-po Dpal, 1280-1307), the nephew of Phagpa came to the throne of Sakya and reigned for thirteen years. The Chinese emperor ordered him to marry as many as seven wives to carry on the legacy of the

40 The Treasury of Lives 2007.

${ }^{41}$ The five sciences (Skt. pañcavidyā, Tib. rig gnas lnga) are five classes of knowledge (Skt. $v i d y \bar{a}$, Tib. rig gnas) of ancient India. The five sciences are: linguistic science (Skt. śabdavidyā, Tib. sgra), logical science (Skt. hetuvidyā, Tib. gtan tshigs), medical science (Skt. cikitsāvidyā, Tib. gso ba), science of fine arts and crafts (Skt. śilpakarmasthānavidyā, Tib. bzo rig pa), and spiritual sciences (Skt. adhyātmavidyā, Tib. nang don rig pa). Gold 2019: 15.

${ }^{42}$ The Treasury of Lives 2007.

${ }_{43}$ Following his example, later Chinese emperors continued the tradition of revering the descendants of Khon lineage as their spiritual preceptors. 
teachings of the forefathers. So Zangpo Pal fathered fifteen sons securing the future of the tradition.

The political system carried out during Phagpa's period continued with the actual powers held by ponchens and the tripons. During the reign of the eldest son of Zangpo Pal, Sonam Gyaltsen (Bsod nams Rgyal mtshan, 1312-1375), the political strength of the Sakya began to wane in Tibet. Most of the later Sakya lamas concentrated more on their religious duties and left the entire political administration to the ponchens and tripons. The immediate victor to emerge from the downfall of Sakya government was one of its tripons, Changchub Gyaltsen (Byang chub Rgyal mtshan, 1302-1364). He and his descendents ruled $\mathrm{U}$ and Tsang for nearly 97 years under the dynastic name of Phagmodru (Phag mo gru, 1354-1618). ${ }^{44}$

Sonam Gyaltsen withdrew to Samye monastery to engage a long meditation retreat. Thus, he came to be known as Lama Samyepa (Bla ma Bsam yas pa), spending much of his later life in the restoration of Samye monastery. He had many famous disciples who excelled in various Buddhist traditions of Tibet for this reason Sonam Gyaltsen may be seen as the root of the "non-secreterian" rime (Tib. ris med) tradition within Tibetan Buddhism. ${ }^{45}$

In 1430 an eminent Sakya master, Ngorchen Kunga Zangpo (Ngor chen Kun dga' Bzang po 1429-1489) founded the Ngor Evam Choden monastery (Ngor E vam Chos ldan) near Sakya and became the head of one of the main subschools of the Sakya tradition. The Ngor lineage was famous for the preservation of the seven mandalas of Ngor. ${ }^{46}$

The other subschool of Sakya was the Tshar lineage, founded by the eclectic Sakya teacher, Tsharchen Losal Gyatso (Tshar chen Blo gsal Rgya mtsho 15021566) who began his Buddhist career as a Gelugpa (Dge lugs pa) monk. He received his novice ordination from the first Dalai Lama, Gedun Gyatso (Dge 'dun Rgya mtsho, 1475-1542) and trained at Tashilhunpo monastery. Nonetheless he had strong faith in the Sakya tradition and in a Sakya master, Kunpang Doringpa (Kun spang Rdo ring pa, 1449-1524), his main teacher. Tsharchen reached a high level of realization but he did not found a new monastic order. The Tshar lineage was established at Dar Drangmoche ('Dar Grang mo che) by his disciples. Many great masters of this lineage, including the fifth Dalai Lama taught at this monastery. ${ }^{47}$

44 Dawa 2001: 56.

45 Chogye 2003: 24.

46 Seven mandalas of Ngor: Guhyasamaja, Hevajra, Chakrasamvara, Vajrayogini, Vajrabhairava, Saravavidya and Mahakala. Smith 2001: 248.

47 Smith 2001: 248-249. 
The third subschool is the Dzongpa tradition founded by Dzongpa Kunga Namgyal (Rdzong pa Kun dga' Rnam rgyal, 1382-1456) and based at Gongkar Dorjeden (Gong dkar Rdo rje gdan). This lineage engaged in a wide religious curriculum based on Indian tantric texts and on commentaries and instructional manuals that were written mainly by Tibetan masters of the Sakya sect. ${ }^{48}$

The Sakya school might be represented as a tree from whose main trunk the Ngor, Tshar and Dzong schools branch out in different directions, but essentially remain connected at the source. The difference between these lineages mainly lies in the various rituals and transmissions they specialize in. ${ }^{49}$ The Ngor tradition became influential in the dissemination of the Sakya tantric teachings and the Tsharpa in the esoteric transmission known as the lamdre lobshe (Tib. lam 'bras slob bshad) or manuals on uncommon lamdre teachings, which contrasts to the more widely taught lamdre tsogshe (Tib. lam 'bras tshogs bshad) or treatises on common lamdre teachings. ${ }^{50}$ There are several independent institutions that share Sakya doctrinal tradition, including Jonang (Jo nang), Bodong (Bo dong), and Bulug/Zhalug (Bu lugs/Zhwa lugs), and which are frequently considered part of the Sakya tradition.

\section{The Khon family in the modern era}

In the $14^{\text {th }}$ century, Kunga Lodro Gyaltsen (Kun dga' Blo gros Rgyal mtshan, 1299-1327), who was the eldest of fifteen grandsons of Sakya Pandita's brother, established four dynastic houses: Zidong (Gzi gdong), Rinchengang (Rin chen sgang), Lhakang (Lha khang) and Ducho Ladrang (Dus mchod Bla brang); out of them only Ducho Ladrang has survived to this day. In the $18^{\text {th }}$ century however, Ducho Ladrang was split between two 'palaces,' namely Dolma Podrang (Sgrol ma Pho brang) and Phuntsog Podrang (Phun tshogs Pho brang).

Pema Dudul Wangchug (Pad ma Bdud 'dul Dbang phyug, 1784-1856) established the Dolma Podrang, whilst Phuntsog Podrang was established by his youngest son, Kunga Rinchen (Kun dga' Rin chen, 1806-1843). Ever since then, the leadership of the Khon Family has alternated between Dolma Podrang

${ }^{48}$ Fermer 2019

${ }^{49}$ Chödung 2016: 25-27.

${ }^{50}$ Generally the lamdre literature could be classified into six parts: 1 . expositions on the Hevajra Tantra (Tib. rgyu bshad), 2. classical lamdre manuscripts (Tib. lam 'bras glegs bam), 3. hagiography of the lineage masters (Tib. bla ma brgyud pa'i rnam thar), 4. treatises on common lamdre teachings (Tib. lam 'bras tshogs bshad), 5. manuals on uncommon lamdre teachings (Tib. lam 'bras slob bshad), 6. liturgy on initiation rites, rituals and Hevajra Sadhana (Tib. dba' da dkyil chog sgrub thabs skor). 
and Phuntsog Podrang. ${ }^{51}$ Two of their descendants in the following generation were the father and paternal uncle of the $41^{\text {st }}$ Sakya Trizin. ${ }^{52}$

His Holiness the $41^{\text {st }}$ Sakya Trizin, Ngawang Kunga (b. 1945) lives with his family in Dehra Dun in North India, after he fled from Tibet in 1959. There he established the Sakya Centre as his seat in India and decades later established a new monastery in Walden, New York, as his seat in the United States. $41^{\text {st }}$ Sakya Trizin frequently travelled abroad to offer the teachings of the Sakya tradition to students from all over the world. ${ }^{53}$ In 2017 after his retirement, the $42^{\text {nd }}$ Sakya Trizin, Ratna Vajra Rinpoche (b. 1974) became the new head of the school. He is the eldest son of the $41^{\text {st }}$ Sakya Trizin, chosen from among the members of the Khon family on the basis of seniority and qualification. ${ }^{54}$ Jetsun Kushog Chime Luding (Rje btsun Sku shogs 'Chi med Klu sdings, b. 1938), the sister of $41^{\text {st }}$ Sakya Trizin, is also a fully qualified lineage holder, as having received religious training alongside her brother in Tibet. Jetsun Kushog currently resides in Canada. ${ }^{55}$

\section{References}

Chogye Trichen Rinpoche 2003. Parting from the Four Attachments: A Commentary on Jetsun Drakpa Gyaltsen's Song of Experience on Mind Training and the View. Boston: Snow Lion. Chödung Karmo Translation Group 2016. A Brief Introduction to Buddhism and the Sakya Tradition. Nepal: International Buddhist Academy Tinchuli-Boudha.

Clauson, Gerard 1959. "The HP'ags-pa Alphabet." Bulletin of the School of Oriental and African Studies 22.1/3: 300-323. https://doi.org/10.1017/S0041977X00068725

Davidson, Ronald M. 2008. Tibetan Renaissance: Tantric Buddhism in the Rebirth of Tibetan Culture. New York: Columbia University Press.

Dawa Norbu 2001. China's Tibet Policy. Richmond: Routledge. https://doi.org/10.4324/ 9780203826959

Dunnel, Ruth 1992. “The Hsia Origins of the Yüan Institution of Imperial Preceptor.” Asia Major (third series) 5.1: 85-111.

Gold, Jonathan C. 2019. The Dharma's Gatekeepers. Sakya Pandita on Buddhist Scholarship in Tibet. Albany: State University of New Yorker Press.

Grousset, René 1970. The Empire of the Steppes: A History of Central Asia. New Jersey: Rutgers University Press.

Hardy, Friedhelm 1999. The World's Religions: The Religions of Asia. Richmond: Routledge.

Hoffmann, Helmut 1975. Tibet. A Handbook. Bloomington: Indiana University Press.

Migmar Tseten 2008. Treasures of the Sakya Lineage: Teachings from the Masters. Boston \& London: Shambhala.

\footnotetext{
${ }^{51}$ Tsem Rinpoche: n.d.

52 Chogye 2003: 25.

${ }_{53}$ Drogmi Buddhist Institute - about the Sakya tradtion. n.d.

${ }^{54}$ Chödung 2016: 25-27.

55 The Sakya Tradition. n.d.
} 
Petech, Luciano 1990. Central Tibet and the Mongols. The Yüan - Sa-skya Period of Tibetan History. Rome: Istituto Italiano per il Medio ed Estremo Oriente.

Sagaster, Klaus 2007. "The History of Buddhism among the Mongols." In: The Spread of Buddhism. Ann Heirman, Stephan Peter Bumbacher (eds.). Leiden, Boston: Brill, 379-432. https://doi.org/10.1163/ej.9789004158306.i-474.99

Smith, Gene E. 2001. Among Tibetan Texts. History and Literature of the Himalayan Plateau. Boston: Wisdom Publications.

Sumegi, Angela 2008. Dreamworlds of Shamanism and Tibetan Buddhism: The Third Place. Albany: State University of New York Press.

Wylie, Turrell V. 1977. "The First Mongol Conquest of Tibet Reinterpreted.” Harvard Journal of Asiatic Studies 37.1: 103-133. https://doi.org/10.2307/2718667

\section{Online sources}

"Drogmi Buddhist Institute" - about the Sakya tradition. n.d. https://www.drogmi.org/about-sakya.html (accessed: 11.04.2020).

Fermer, Mathias 2019. Dzongpa Tradition. https://dzongpaliterature.org (accessed: 11.04.2020).

"Sakya Heritage Society" - Sakya Tibetan Buddhist heritage. n.d. http://www.sakyaheritage.org/ DharmaLineage (accessed: 11.04.2020).

“The Sakya Tradition.” n.d. Khacho Yulo Ling Buddhist Centre. https://www.yuloling.com/buddhism/buddhism/sakya-tradition.html (accessed: 11.04.2020).

"The Treasury of Lives" - a biographical encyclopedia of Tibet, Inner Asia, and the Himalayan region. 2007. https://treasuryoflives.org (accessed: 11.04.2020).

Tsem Rinpoche: Disharmony Within the Sakya? - brief overview of the Sakya tradition. n.d. https://www.tsemrinpoche.com/tsem-tulku-rinpoche/buddhas-dharma/disharmony-within-the-sakya.html (accessed: 11.04.2020). 